\title{
RELEVANSI SISTEM PENDIDIKAN PESANTREN TRADISIONAL DALAM ERA MODERNISASI
}

\author{
Dr. H. M. Syukron Djazilam, S.Ag, M.Pd.I \\ Dosen Universitas Nahdlatul Ulama Surabaya.
}

\begin{abstract}
Abstrak :
Pesantren merupakan lembaga pendidikan asli Indonesia yang mempunyai akar tradisi kuat dilingkungan masyarakat. Dalam era modernisasi atau kemajuan ilmu pengetahuan dan teknologi dewasa ini, Ia merupakan salah satu lembaga pendidikan Islam tradisional dengan tujuan utama pendidikan di dalamnya adalah membentuk kepribadian yang utuh, integrited, dan kaffah. Kegiatan pendidikan bukan hanya berorientasi pada transfer ilmu, tapi juga tuntunan dan tuntunan untuk mengamalkannya. Pesantren mayoritas hanya mengajarkan ilmu-ilmu agama Islam (kitab kuning) sebagai inti kurikulumnya, serta tidak mengajarkan pengetahuan umum. Kurikulum pesantren ditetapkan secara mandiri oleh kyai dan tidak memasukkan kurikulum negeri.

Di samping itu, era modernisasi sekarang ini, kemajuan IPTEK terutama dengan system IT-nya menjadi sumber kemudahan di segala lini kehidupan. Oleh karenanya wajar jika relevansi sistem pendidikan pesantren tradisional menjadi pertanyaan banyak pihak untuk tetap dipertahankan. Tulisan ini disusun sekaligus sebagai bahan masukan bagi pengelola pendidikan pesantren tradisional mengenai berbagai kelemahan yang ada selama ini dan alternatif pemecahannya demi eksistensi pesantren di masa yang akan datang.
\end{abstract}

Kata Kunci : Sistem pendidikan pesantren, Relevansi, Era Modernisasi

\section{A. Pendahuluan}

Kehidupan sosial budaya bangsa Indonesia sangat dipengaruhi dan diwarnai oleh nilainilai agama sehingga kehidupan beragama tidak dapat dipisahkan dari kehidupan bangsa Indonesia. Sebagai negara yang berdasarkan agama, pendidikan agama tidak dapat diabaikan dalam penyelengaraan pendidikan nasional. Umat beragama beserta lembaga-lembaga keagamaan di Indonesia merupakan potensi besar dan sebagai modal dasar dalam pembangunan mental spiritual bangsa dan merupakan potensi nasional untuk pembangunan fisik materiil bangsa Indonesia ${ }^{1}$. Hal ini sesuai dengan tujuan pembangunan nasional, yaitu pembangunan masyarakat seutuhnya dan

\footnotetext{
${ }^{1}$ Hanun Asrorah, Sejarah Pendidikan Islam (Jakarta: Logos Wacana ilmu, 1999), 181.
} 
masyarakat adil dan makmur berdasarkan Pancasila dan UUD 1945. Oleh kaena itu, agama tidak dapat dipisahkan dengan penyelenggaraan pendidikan nasional Indonesia.

Pesantren secara historis telah mendokumentasikan berbagai peristiwa sejarah bangsa Indonesia. Sejak awal penyebaran agama Islam di Indonesia, pesantren merupakan saksi utama dan sarana penting bagi kegiatan Islamisasi tersebut. Perkembangan dan dan kemajuan masyarakat Islam Nusantara, tidak mungkin terpisahkan dari peranan yang dimainkan pesantren. Besarnya arti pesantren dalam perjalanan bangsa Indonesia yang harus dipertahankan. Apalagi pesantren telah dianggap sebagai lembaga pendidikan yang mengakar kuat dari budaya asli bangsa Indonesia. ${ }^{2}$ Kehadiran pesantren sebagai lembaga pendidikan Islam, kini semakin diminati oleh banyak kalangan, termasuk masyarakat kelas menengah atas. Hal ini membuktikan lembaga ini mampu memberikan solusi terhadap kebutuhan pendidikan anak-anak mereka. Menurut data di Departemen Agama pada tahun 1998, bahwa dari 8.991 pondok pesantren saat itu, terdapat 1.598 berada diwilayah perkotaan sedangkan yang ada diwilayah pedesaan sebanyak 7. 393. Data ini menunjukan adanya pergeseran jumlah pesantren yang ada di perkotaan dari tahun ke tahun. Dengan melihat kecenderunggan ini, diprediksi suatu saat nanti akan terjadi pertimbangan jumlah pesantren antar kota dan desa. ${ }^{3}$

Menurut Malik Fadjar, kelebihan pondok pesantren dapat dilihat dari polemik kebudayaan yang berlangsung pada tahun 30-an. Dr. Sutomo, salah seorang cendikiawan yang telibat dalam polemik tersebut, menganjurkan agar asas-asas sistem pendidikan pesantren digunakan sebagai dasar pembangunan pendidikan nasional. Walaupun pemikiran Dr. Sutomo itu kurang mendapat tanggapan yang berarti, tetapi patut digaris bawahi bahwa pesantren telah dilihat sebagai bagian yang tidak terpisahkan dalam proses pembentukan identitas budaya bangsa Indonesia. Pada tahun 70-an, Abdurrahman Wahid telah mempopulerkan pesantren sebagai subkultur dari bangsa Indonesia. Sekarang ini, umat Islam sendiri tampaknya telah menganggap

\footnotetext{
${ }^{2}$ Hanun Asrohah, Sejarah Pendidikan, 184

${ }^{3}$ Malik Fadjar, Visi Pembharuan Pendidikan Islam (Jakarta: LP3N, 1998), 125.
} 
pesantren sebagai model institusi pendidikan yang memiliki keunggulan, baik dari sisi transmisi dan internalisasi moralitas umat Islam $^{4}$ maupun dari aspek tardisi keilmuan yang oleh Martin Van Bruinessen dinilainya sebagai salah satu tradisi agung (great tradition). ${ }^{5}$ Akan tetapi di samping hal-hal yang mengembirakan tersebut di atas, perlu pula dikemukakan beberapa tantangan pondok pesantren dewasa ini. Tantangan yang dialami lembaga ini menurut pengamatan para ahli semakin lama semakin banyak, kompleks, dan mendesak. Hal ini disebabkan oleh kemajuan ilmu pengetahuan dan teknologi (IPTEK). Ditengah derap kemajuan ilmu dan teknologi yang menjadi motor bergeraknya modernisasi, dewasa ini banyak fihak merasa ragu terhadap eksistensi lembaga pendidikan pesantren. Keraguan itu dilatar belakangi oleh kecenderungan dari pesantren untuk bersikap menutup diri terhadap perubahan di sekelilingnya dan sikap kolot dalam merespon upaya modernisasi. Menurut Azyumardi Azra, kekolotan pesantren dalam mentransfer hal-hal yang berbau modern itu merupakan sisa-sisa dari respon pesantren terhadap kolonial Belanda. Lingkungan pesantren merasa bahwa sesuatu yang bersifat modern, yang selalu mereka anggap datang dari barat, berkaitan dengan penyimpangan terhadap agama. ${ }^{6}$ Oleh sebab itu, mereka melakukan isolasi diri terhadap sentuhan perkembangan modern sehingga membuat pesantren dinilai sebagai penganut Islam tradisional.

Perkembangan dunia telah melahirkan suatu kemajuan zaman yang modern. Perubahan-perubahan yang mendasar dalam struktur budaya masyarakat seringkali membentur pada aneka kemapanan. Akibatnya ada keharusan untuk mengadakan upaya kontekstualisasi bangunan-bangunan budaya masyrakat dengan dinamika modernisasi, tak terkecuali dengan sistem pendidikan pesantren. Karena itu, sistem

\footnotetext{
${ }^{4}$ Ibid. 126

${ }^{5}$ Martin Van Bruinessen, Kitab Kuning, Pesantren, dan Tarekat : Tradisi-Tradisi Islam di Indonesia (Bandung:

Mizan, 1999), 17.

${ }^{6}$ Azumardi Azra, "Pesantren : Kontinuitas dan Perubahan", Pengantar dalam Nucholis Madjid, Bilik-Bilik Pesantren : Sebuah Potret Perjalanan (Jakarta : Paramida, 1997), xvi.
} 
pendidikan pesantren harus melakukan upayaupaya konstruktif agar tetap relevan dan mampu bertahan. ${ }^{7}$

\section{B. Sistem Pendidikan Pesantren}

Pada dasarnya pesantren adalah lembaga pendidikan Islam, di mana pengetahuanpengetahuan yang berhubungan dengan agama Islam diharapkan dapat diperoleh di pesantren. Apa pun usaha yang dilakukan untuk meningkatkan pesantren di masa kini dan masa yang akan datang harus tetap pada prinsip ini. Tujuan pendidikan pesantren tidak semata-mata untuk memperkaya pikiran murid dengan penjelasan-penjelasan, tetapi untuk meninggikan moral, melatih dan mempertinggi semangat, menghargai nilai-nilai spiritual dan kemanusiaan, mengajarkan sikap dan tingkah laku yang jujur dan bermoral, serta menyiapkan para murid untuk hidup sederhana dan bersih hati. Selain itu, tujuan pendidikan pesantren bukanlah untuk mengejar kekuasaan, uang dan keagungan duniawi, tetapi ditanamkan kepada mereka bahwa belajar adalah semata-mata kewajiban dan pengabdian kepada Tuhan. ${ }^{8}$ Tujuan ini pada gilirannya akan menjadi faktor motivasi bagi para santri untuk melatih diri menjadi seorang yang ikhlas di dalam segala amal perbuatannya dan dapat berdiri sendiri tanpa menggantungkan sesuatu kecuali kepada Tuhan. Dengan demikian dapat disimpulkan bahwa secara umum tujuan pendidikan pesantren adalah mendidik manusia yang mandiri, berakhlak mulia, serta bertaqwa.

Berdasarkan tujuan pendidikan pesantren seperti di atas, maka yang paling ditekankan adalah pengembangan watak pendidikan individual. Santri dididik sesuai dengan kemampuan dan keterbatasan dirinya, sehingga di pesantren dikenal prinsipprinsip dasar belajar tuntas dan maju berkelanjutan. Bila di antara para santri ada yang memiliki kecerdasan dan keistimewaan dibandingkan dengan yang lainnya, mereka akan diberi perhatian khusus dan selalu didorong untuk terus mengembangkan diri, serta menerima kuliah pribadi secukupnya. Para santri diperhatikan tingkah laku

\footnotetext{
${ }^{7}$ Suwendi, "Rekonstruksi Sistem Pendidikan Pesantren : Beberapa Catatan", dalam Pesantren Masa Depan, 216.

${ }^{8}$ Dhofier, Tradisi Pesantren, 21. ${ }^{9}$ Dhofier, Tradisi Pesantren, 22.
} 
moralnya dan diperlakukan sebagai makhluk yang terhormat sebagai titipan Tuhan yang harus disanjung. Kepada mereka ditanamkan perasaan kewajiban dan tanggung jawab untuk melestarikan dan menyebarkan pengetahuan mereka tentang Islam kepada orang lain, serta mencurahkan segenap waktu dan tenaga untuk belajar terus menerus sepanjang hidup. ${ }^{9}$

Dalam sistem pendidikan pesantren tradisional tidak dikenal adanya kelaskelas sebagai tingkatan atau jenjang pendidikan. Seseorang dalam belajar di pesantren tergantung sepenuhnya pada kemampuan pribadinya dalam menyerap ilmu pengetahuan. Semakin cerdas seseorang, maka semakin singkat ia belajar. ${ }^{9}$ Menurut tradisi pesantren, pengetahuan seorang santri diukur dari jumlah buku-buku atau kitab-kitab yang telah pernah dipelajarinya dan kepada ulama mana ia telah berguru. Jumlah kitab-kitab standar berbahasa Arab yang harus dibaca (kutubul muqarrarah) telah ditentukan oleh lembaga-lembaga pesantren. Dengan demikian, dalam pesantren tradisional kitabkitab Islam klasik (kitab kuning) dijadikan mata kajian, sekaligus sebagai sarana penjenjangan kemampuan santri dalam belajar. Satuan waktu belajar tidak ditentukan oleh kurikulum atau usia, melainkan oleh selesainya kajian satu atau beberapa kitab yang ditetapkan. Pengelompokan kemampuan santri juga tidak didasarkan semata-mata kepada usia, tetapi kepada taraf kemampuan santri dalam mengkaji dan memahami kitab-kitab tersebut. ${ }^{10}$

Dalam pesantren tradisional, untuk menentukan kitab mana yang akan dikaji dan diikuti oleh seorang santri tidak secara ketat ditentukan oleh kyai atau pesantren, melainkan justru diserahkan kepada santri itu sendiri. Hal ini karena santri yang meneruskan ke pesantren, terutama pesantren besar, dianggap telah mampu untuk mengukur kemampuannya, sehingga pesantren atau kyai hanya membimbing tentang cara menentukan pilihan kajian. Pemilihan materi belajar yang memberikan

\footnotetext{
9 Arifin, Imron. Kepemimpinan Kyai : Kasus Pondok Pesantren Tebuireng. (Malang : Kalimasahada Press, 1993)37.

${ }^{10}$ A. Wahid Zaini, "Orientasi Pondok Pesantren Tradisional Dalam Masyarakat Indonesia", dalam Tarekat, Pesantren, dan Budaya Lokal, ed. M. Nadim Zuhdi et. al. (Surabaya : Sunan Ampel Press, 1999), 79. ${ }^{12}$ Ibid., 80.
} 
keleluasaan kepada santri untuk ikut mengambil peranan di dalam menentukan jenjang dan kurikulum belajarnya oleh sebagian peneliti dianggap sebagai adanya proses demokratisasi di dalam proses belajar mengajar. ${ }^{12}$

Sistem pengajaran di pesantren dalam mengkaji kitab-kitab Islam klasik (kitab kuning) sejak mula berdirinya menggunakan metode sebagai berikut :

Metode sorogan, di mana santri menghadap guru seorang demi seorang dengan membawa kitab yang akan dipelajarinya. Kyai membacakan pelajaran yang berbahasa Arab itu kalimat demi kalimat kemudian menterjemahkannya dan menerangkan maksudnya. Sedangkan santri menyimak dan memberi catatan pada kitabnya untuk mensahkan bahwa ilmu itu telah diberikan oleh kyai. Adapun istilah sorogan tersebut berasal dari kata sorog (bahasa Jawa) yang berarti menyodorkan, sebab setiap santri menyodorkan kitabnya di hadapan kyainya. Di pesantren besar, sorogan dilakukan oleh dua atau tiga orang santri saja yang biasanya terdiri dari keluarga kyai atau santri-santri yang diharapkan di kemudian hari menjadi ulama.

Metode wetonan, di mana para santri mengikuti pelajaran dengan duduk di sekeliling kyai yang menerangkan pelajaran secara kuliah. Santri membawa kitab yang sama dengan kitab kyai dan menyimak kitab masing-masing serta membuat catatan padanya. Istilah wetonan ini berasal dari kata wektu (bahasa Jawa) yang berarti waktu, sebab pengajian tersebut diadakan dalam waktuwaktu tertentu, yaitu sebelum atau sesudah melakukan shalat fardhu. Di Jawa Barat metode ini disebut dengan bandongan, sedangkan di Sumatra dipakai istilah halaqah. Dalam sistem pengajaran semacam ini tidak dikenal adanya absensi. Santri boleh datang boleh tidak, juga tidak ada ujian. ${ }^{11}$

Dua metode pengajaran di atas dalam waktu yang sangat panjang masih dipergunakan pesantren secara agak seragam. Metode sorogan tentu lebih efektif, karena kemampuan santri dapat terkontrol secara langsung oleh kyai (ustadz). Akan tetapi metode tersebut sangat tidak efisien, karena terlalu memakan waktu lama.

11 M. Habib Chirzin, “Agama dan Ilmu dalam Pesantren”, dalam Pesantren dan Pembaharuan, ed. M. Dawam Rahardjo (Jakarta : LP3ES, 1988), 88. 
Sedangkan metode wetonan akan lebih efisien, namun sangat kurang efektif, karena kemampuan santri tidak akan terkontrol oleh pengajarnya. Meskipun demikian, dalam kedua metode tersebut budaya tanya jawab dan perdebatan tidak dapat tumbuh. Terkadang terjadi kesalahan yang diperbuat oleh sang kyai (ustadz), namun tidak pernah ada teguran atau kritik dari santri. Bahkan, tidak mustahil tanpa pikir panjang para santri menerima mentah-mentah kesalahan tersebut sebagai kebenaran. ${ }^{12}$

Sekarang ini, beberapa pesantren tradisional tetap bertahan dengan kedua sistem pengajaran tersebut tanpa variasi ataupun perubahan. Sedangkan sebagian yang lain telah berubah sesuai dengan perubahan zaman dan mulai menerapkan sistem pendidikan klasikal yang dianggap lebih efektif dan efisien. Sistem yang disebut terakhir ini mulai muncul dan berkembang di awal tahun 1930-an. Modelnya seperti sekolah pada umumnya, meskipun kurikulum dan silabusnya sangat bergantung pada kyai, dalam arti dapat berubah-ubah sesuai dengan pertimbangan dan kebijaksanaan kyai. Ini semua masih dalam satu pembicaraan, yaitu hanya pelajaran agama atau kitab-kitab kuning saja yang diajarkan. ${ }^{15}$

Sistem evaluasi yang berlaku di dalam pesantren tradisional biasanya tidak terlalu ketat dan mengikat, melainkan sangat memberi keleluasaan kepada santri yang bersangkutan untuk melakukan self-evaluation (evaluasi diri sendiri). Dalam evaluasi pengajaran ini, peranan kyai sangat menonjol dan lebih besar pada metode sorogan, sementara pada metode wetonan para santri sangat mempunyai peranan. Biasanya titik tekan evaluasi yang dilakukan oleh kyai dan pengurus pesantren tidak sekedar pada pengetahuan kognitif, berupa sejauh mana keberhasilan penyerapan ilmu dan pengetahuan yang telah diperoleh santri, tetapi lebih jauh lagi pada keutuhan kepribadiannya berupa ilmu, sikap, dan tindakan --tutur kata dan perbuatan-- yang terpantau dalam interaksi keseharian santri dengan kyai. Dalam menentukan apakah seorang santri telah berhasil menyelesaikan suatu kurikulum tertentu, dengan demikian tidak sekedar dinilai dari aspek penguasaan intelektualnya, melainkan juga

\footnotetext{
12 Ahmad Qodri A. Azizy, Islam dan Permasalahan Sosial : Mencari Jalan Keluar (Yogyakarta : LKIS, 2000), 106. ${ }^{15}$ Ibid., 107.
} 
integritas kepribadian santri yang bersangkutan yang dinilai dari kiprah dan tingkah laku kesehariannya. ${ }^{13}$

Proses pendidikan di pesantren berlangsung selama 24 jam. Dalam pesantren tradisional, penjadwalan waktu belajar tidaklah terlalu ketat. Timing dan alokasi waktu bagi sebuah kitab yang dikaji biasanya disepakati bersama oleh kyai dan santri sesuai dengan pertimbangan kebutuhan dan kepentingan bersama. Dapat saja waktu 24 jam hanya dimanfaatkan empat atau lima jam untuk istirahat, sedangkan sisanya untuk proses belajar mengajar dan beribadah, baik secara kolektif maupun secara individual. Pendidikan pesantren sangat menekankan aspek etika dan moralitas. Proses pendidikan di sini merupakan proses pembinaan dan pengawasan tingkah laku santri yang seharusnya merupakan cerminan ilmu yang telah diperoleh. Pembinaan dan pengawasan ini dilakukan bersamaan dengan peneladanan langsung oleh kyai dan pengurus sebagai kepanjangan tangan dari kyai, mulai dari urusan ibadah sampai pada urusan keseharian santri. ${ }^{14}$

Dalam pesantren tradisional dikenal pula sistem pemberian ijazah, tetapi bentuknya tidak seperti yang dikenal dalam sistem modern. Ijazah di pesantren berbentuk pencantuman nama dalam suatu daftar rantai transmisi pengetahuan yang dikeluarkan oleh gurunya terhadap muridnya yang telah menyelesaikan pelajarannya dengan baik tentang suatu kitab tertentu sehingga si murid tersebut dianggap menguasai dan boleh mengajarkannya kepada orang lain. Tradisi ijazah ini hanya dikeluarkan untuk murid-murid tingkat tinggi dan hanya mengenai kitab-kitab besar dan masyhur. Para murid yang telah mencapai suatu tingkatan pengetahuan tertentu tetapi tidak dapat mencapai ke tingkat yang cukup tinggi disarankan untuk membuka pengajian, sedangkan yang memiliki ijazah biasanya dibantu mendirikan pesantren. ${ }^{15}$

Pesantren modern merupakan tipe pesantren yang mempunyai ciri berlainan dengan pesantren tradisional dan sering diperhadapkan secara vis a vis (berlawanan)

\footnotetext{
${ }^{13}$ Zaini, “Orientasi Pondok Pesantren”, 80.

14 Zaini, "Orientasi Pondok Pesantren", 81-82.

${ }^{15}$ Dhofier, Tradisi Pesanten, 23.
} 
dengan pesantren tradisional. Ciri pertama dari pesantren modern adalah meluasnya mata kajian yang tidak terbatas pada kitab-kitab Islam klasik saja, tetapi juga pada kitab-kitab yang termasuk baru, di samping telah masuknya ilmu-ilmu umum dan kegiatan-kegiatan lain seperti pendidikan ketrampilan dan sebagainya. Penjenjangan pendidikannya telah mengikuti seperti yang lazim pada sekolah-sekolah umum, meliputi SD/Tingkat Ibtidaiyah, SMP/Tingkat Tsanawiyah, SMU/Tingkat Aliyah, dan bahkan Perguruan Tinggi. Sistem pengajaran dalam pesantren modern tidak sematamata tumbuh atas pola lama yang bersifat tradisional, tetapi juga telah dilakukan suatu inovasi dalam pengembangan sistem pengajaran tersebut. Sistem pengajaran yang diterapkan tersebut adalah sistem klasikal, sistem kursus-kursus, dan sistem pelatihan yang menekankan pada kemampuan psikomotorik. ${ }^{16}$

Ciri kedua pesantren modern adalah hadirnya warna pengelolaan (perencanaan, koordinasi, penataan, pengawasan, dan evaluasi) yang sudah diwarnai oleh konsep-konsep pengelolaan baru, yang merupakan serapan dari konsep-konsep yang ada di luar pesantren. Pengelolaan ini juga meliputi pola pendekatan dan teknologi yang digunakan. Masuknya komputer ke dalam sistem manajemen pesantren, digunakannya metodologi pendidikan yang diserap dari ilmu pendidikan, digunakannya jasa perbankan dalam sistem pengelolaan keuangan, dan berintegrasinya sistem evaluasi pesantren ke dalam sistem evaluasi pendidikan nasional, merupakan beberapa ciri lain yang dapat disebut untuk menunjuk pada hadirnya bentuk pengelolaan pesantren yang sudah diwarnai oleh warna baru itu. ${ }^{17}$

Sementara itu pesantren komprehensif merupakan satu kategori pesantren yang berusaha mempertemukan beberapa unsur dari kedua tipologi pesantren terdahulu. Dalam pesantren tipe terakhir ini akan terlihat ciri kedua pondok pesantren yang disebut terdahulu. Misalnya pada satu sisi dengan hadirnya sistem klasikal pada sistem pengajarannya sama seperti pesantren modern dan sekolah-sekolah umum pada

\footnotetext{
${ }^{16}$ Ghazali, Bahri. Pendidikan Pesantren Berwawasan Lingkungan (Jakarta : Pedoman Ilmu Jaya, 2001), 32.

${ }^{17}$ Zaini, “Orientasi Pondok Pesantren”, 82-83.
} 
lazimnya, sementara di sisi lain dengan tetap menggunakan kitab kuning sebagai batasan kurikulumnya masih sama seperti pondok pesantren tradisional. Selain itu, kurikulum pesantren ini biasanya juga ditambah dengan beberapa mata pelajaran umum yang mempunyai kaitan erat dengan ilmu agama, seperti matematika yang berkaitan dengan ilmu waris, falak, dan sebagainya. ${ }^{18}$

\section{Pendidikan Dan Era Modernisasi}

Pendidikan secara mudah dapat diartikan sebagai usaha manusia untuk membina kepribadiannya sesuai dengan nilai-nilai di dalam masyarakat dan kebudayaan. ${ }^{19}$ Dengan demikian, bagaimanapun sederhananya peradaban suatu masyarakat, di dalamnya terjadi atau berlangsung suatu proses pendidikan. Oleh karenanya sering pula dikatakan bahwa pendidikan telah ada sepanjang sejarah peradaban umat manusia.

Sementara itu, beberapa ahli telah mengemukakan definisi pendidikan secara berbedabeda. Ahmad D. Marimba menyatakan bahwa pendidikan adalah "bimbingan atau pimpinan secara sadar oleh pendidik terhadap perkembangan jasmani dan rohani anak didik menuju terbentuknya kepribadian yang utama." ${ }^{20}$ Dengan kata lain, pendidikan pada hakekatnya adalah usaha orang dewasa secara sadar untuk membimbing kepribadian dan kemampuan dasar anak didik supaya berkembang secara maksimal sesuai dengan tujuan yang dicita-citakan.

Sedangkan Modernisasi berasal dari kata modern yang berarti terbaru, mutakhir, atau sikap dan cara berpikir yang sesuai dengan tuntutan zaman. Selanjutnya modernisasi diartikan sebagai proses pergeseran sikap dan mentalitas sebagai warga masyarakat untuk bisa hidup sesuai dengan tuntutan masa kini. ${ }^{21}$

\footnotetext{
${ }^{18}$ Zaini, "“ Pondok Pesantren”, 83.

${ }^{19}$ Tim Dosen FIP-IKIP Malang, Pengantar Dasar-Dasar Kependidikan (Surabaya : Usaha Nasional, 1981), 2.

${ }^{20}$ Ahmad D. Marimba, Pengantar Filsafat Pendidikan Islam (Bandung : Al-Ma'arif, 1974), 20.

${ }^{21}$ Depdikbud RI, Kamus Besar Bahasa Indonesia (Jakarta : Balai Pustaka, 1989), 589.
} 
Menurut Nurcholish Madjid, pengertian modernisasi hampir identik dengan pengertian rasionalisasi, yaitu proses perombakan pola berpikir dan tata kerja lama yang tidak rasional dan menggantinya dengan pola berpikir dan tata kerja baru yang rasional. Hal itu dilakukan dengan menggunakan penemuan mutakhir manusia di bidang ilmu pengetahuan. ${ }^{22}$ Sementara Koentjaraningrat, sebagaimana dikutip Faisal Ismail, mendefinisikan modernisasi sebagai suatu usaha secara sadar yang dilakukan oleh suatu bangsa atau negara untuk menyesuaikan diri dengan konstelasi dunia pada suatu kurun tertentu di mana bangsa itu hidup. ${ }^{23}$ Dengan pengertian terakhir ini, usaha dan proses modernisasi itu selalu ada dalam setiap kurun atau zaman. Kesimpulannya, modernisasi adalah suatu usaha secara sadar untuk menyesuaikan diri dengan konstelasi dunia dengan menggunakan kemajuan ilmu pengetahuaan, untuk kebahagiaan hidup sebagai perorangan, bangsa, atau umat manusia.

Lucian W. Pye, sebagaimana dikutip Aqiel Siradj, mengemukakan bahwa modernisasi adalah budaya dunia. Menurutnya, proses mondial ini tercipta karena kebudayaan modern senantiasa didasarkan pada : (a) teknologi yang maju dan semangat dunia ilmiah; (b) pandangan hidup yang rasional; (c) pendekatan sekuler dalam hubungan-hubungan sosial; (d) rasa keadilan sosial dalam masalah-masalah umum, terutama dalam bidang politik; dan (e) menerima keyakinan bahwa unit utama politik mesti berupa negara-kebangsaan. ${ }^{24}$ Selanjutnya pada taraf individual, Alex Inkeles dan David H. Smith mengemukakan ciri-ciri manusia modern sebagai berikut : (a) siap menerima pengalaman baru dan terbuka untuk perubahan, inovasi, dan pembaharuan; (b) mampu membentuk pendapat tentang sejumlah masalah dan isu yang timbul; (c) bersikap demokratis terhadap berbagai pendapat yang ada; (d) berorientasi kepada masa sekarang dan masa depan, sehingga lebih berdisiplin dalam

\footnotetext{
${ }^{22}$ Nurcholish Madjid, Islam, Kemodernan, dan Keindonesiaan (Bandung : Mizan, 1997), 172.

23 Ismail, Faisal. Paradigma Kebudayaan Islam : Studi Kritis dan Refleksi Historis (Yogyakarta : Titian Ilahi Press, 1998) 196.

${ }^{24}$ Sa'id Aqiel Siradj, "Khazanah Pemikiran Islam dan Peradaban Modern”, dalam Pesantren Masa Depan : Wacana Pemberdayaan dan Transformasi Pesantren, ed. Marzuki Wahid et. al. (Bandung : Pustaka Hidayah, 1999), 27. ${ }^{28}$ Siradj, "Khazanah Pemikiran”, 28.
} 
waktu; (e) berorientasi pada perencanaan serta pengorganisasian sebagai suatu cara mengatur kehidupan; (f) dapat menguasai lingkungan dan tidak sebaliknya dikuasai oleh lingkungannya; (g) percaya bahwa segala sesuatu dapat diperhitungkan; (h) mempunyai kesadaran terhadap orang-orang lain dan cenderung bersikap respek terhadap mereka; (i) percaya pada ilmu dan teknologi; (j) percaya pada keadilan distribusi atau keadilan yang didasarkan pada kontribusi dan partisipasi. ${ }^{28}$ Walaupun ciri-ciri manusia modern di atas belum diterima secara universal, namun ciri-ciri tersebut dapat memberikan gambaran dan ukuran yang dapat dijadikan pegangan mengenai manusia modern. Dengan demikian, siapa pun orang yang memiliki ciri-ciri tersebut berhak disebut modern.

\section{Pendidikan Pesantren dan Modernisasi Pendidikan}

Institusi pendidikan di Indonesia yang mengenyam sejarah paling panjang di antaranya adalah pesantren. Institusi ini lahir, tumbuh dan berkembang telah lama. Bahkan, semenjak belum dikenalnya lembaga pendidikan lainnya di Indonesia, pesantren telah hadir lebih awal.

Dalam kesejarahannya yang amat panjang itu, pesantren terus berhadapan dengan banyak rintangan, diantaranya pergulatan dengan modernisasi. M. Dawam Raharjo, salah seorang pemikir muslim Indonesia, pernah menuduh bahwa pesantren merupakan lembaga yang kuat dalam mempertahankan keterbelakangan dan ketertutupan. Dunia pesantren memperlihatkan dirinya bagaikan bangunan luas, yang tak pernah kunjung berubah. Ia menginginkan masyarakat luar berubah. Oleh karena itu, ketika isu-isu modernisasi dan pembangunan yang dilancarkan oleh rezim negara jelas orientasinya adalah pesantren. Dalam kaitannya dengan peran tradisionalnya, pesantren kerap diidentifikasi memiliki peranan penting dalam masyarakat Indonesia, antara lain: sebagai pusat berlangsungnya transmisi ilmu-ilmu Islam tradisional, sebagai penjaga dan pemelihara keberlangsungan Islam tradisional, dan sebagai pusat reproduksi ulama' 25 .

\footnotetext{
${ }^{25}$ Suwendi, "Sejarah dan Pemikiran Pendidikan Islam", (Jakarta: 2004) Hal 157.
} 
Dalam proses pembelajaran di pesantren, ilmu-ilmu keIslaman memang menjadi prioritas utama, untuk tidak mengatakan satu-satunya. Hal ini antara lain tampak dari kurikulum yang berlaku. Sebagaimana diketahui, kitab kuning berisi pembahasan tentang berbagai ilmu ke Islaman tradisional, yang dalam banyak aspek tidak memiliki hubungan langsung dengan ilmu-ilmu modern.

Sejalan dengan dinamika kehidupan masyarakat, pesantren mengalami perubahan dan perkembangan yang berarti. Diantaranya perubahan-perubahan yang paling penting menyangkut penyelengaraan pendidikan. Dewasa ini tidak sedikit pesantren di Indonesia telah mengadopsi sistem pendidikan formal seperti yang diselenggarakan pemerintah. Pada umumnya pilihan pendidikan formal yang didirikan di pesantren masih berada pada jalur pendidikan Islam. Namun demikian, banyak pula pesantren yang sudah memiliki lembaga pendidikan sistem sekolah seperti dikelola oleh Depdikbud. Beberapa pesantren bahkan sudah membuka perguruan tinggi, baik berupa Institut Agama Islam maupun Universitas. ${ }^{26}$

Di pesantren-pesantren tersebut, sistem pembelajaran tradisional yang berlaku pada pesantren tradisional mulai diseimbangkan dengan sistem pembelajaran modern. Dalam aspek kurikulum, misalnya, pesantren tidak lagi hanya memberikan mata pelajaran ilmu-ilmu Islam, tetapi juga ilmu-ilmu umum modern yang diakomodasi dari kurikulum pemerintah. Dalam hal ini, mata pelajaran umum menjadi mata pelajaran inti, disamping mata pelajaran agama yang tetap dipertahankan. Begitu pula dalam pesantren yang baru ini, sistem pengajaran yang berpusat pada kyai mulai ditingalkan. Pihak pesantren umumnya merekrut lulusan-lulusan perguruan tinggi untuk menjadi pengajar di sekolah-sekolah yang di dirikan oleh pengelola pesantren.

Semua perubahan itu sama sekali tida mencabut pesantren dari peran tredisionalnya sebagai lembaga yang banyak bergerak di bidang pendidikan Islam, terutama dalam pengertiannya sebagai lembaga "tafaqquh fi al-din". Sebaliknya, hal tersebut justru semakin memperkaya sekaligus mendukung upaya transmisi khazanah pengetahuan Islam trdisional sebagaimana di muat dalam "kitab kuning" dan

\footnotetext{
${ }^{26}$ Dr. Husni rahim, "Arah Baru Pendidikan Islam di Indonesia", (Jakarta: PT. Logos Wacana Ilmu 2001. Hal 148
} 
melebarkan jangkauan pelayanan pesantren terhadap tuntutan dan kebutuhan masyarakat, terutama di bidang pendidikan formal. Dengan ungkapan lain, proses perubahan seperti dijelaskan diatas merupakan salah satu bentuk modernisasi pesantren sebagai lembaga pendidikan maupun lembaga sosial.

Namun, dalam proses perubahan tersebut, pesantren tampaknya dihadapkan pada keharusan merumuskan kembali sistem pendidikan yang di selenggarakan. Di sini, pesantren tengah berada dalam proses pergumulan antara "identitas dan keterbukaan". Di satu pihak, pesantren di tuntut untuk menemukan identitasnya kembali sebagai lembaga pendidikan Islam. Sementara di pihak lain, ia juga harus bersedia membuka diri terhadap sistem pendidikan modern yang bersumber dari luar pesantren. Salah satu agenda penting pesantren dalam kehidupan dewasa ini adalah memenuhi tantangan modernisasi yang menuntut tenaga trampil di sektor-sektor kehidupan modern.

Dalam kaitan dengan modernisasi ini, pesantren diharapkan mampu menyumbangkan sumber daya manusia yang dibutuhkan dalam kehidupan modern. Mempertimbangkan proses perubahan di pesantren, tampaknya bahwa hingga dewasa ini pesantren telah memberi kontribusi penting dalam menyelengarakan pendidikan formal dan modern. Hal ini berarti pesantren telah berperan dalam perkembangan dunia pendidikan di Indonesia. Meskipun demikian, dalam konteks peningkatan mutu pendidikan dan perluasan akses masyarakat dari segala lapisan sosial terhadap pendidikan, peran pesantren tidak hanya perlu ditegaskan, tetapi mendesak untuk dilibatkan secara langsung 27 .

\section{E. Relevansi Pendidikan Pesantren Dalam Era Modern.}

Gelombang modernisasi sistem pendidikan di Indonesia pada awalnya tidak di kumandangkan oleh kalangan muslim. Sistem pendidikan modern pertama yang pada gilirannya mempengaruhi sistem pendidikan Islam justru di perkenalkan oleh

\footnotetext{
2731 Ibid. 150.
} 
pemerintah koloniah Belanda, terutama dengan mendirikan volkschoolen, sekolah rakyat atau desa. Sebenarnya sekolah desa ini pada awalnya cukup mengecewakan, lantaran tingkat putus sekolah yang sangat tinggi dan mutu pelajaran yang amat rendah. Namun di sisi lain, eksperimentasi Belanda dengan sekolah desa atau sekolah negari, sejauh dalam kaitannya dengan sistem dan kelembagaan pendidikan Islam, merupakan transformasi sebagian surau di Minagkabau menjadi sekolah nagari model Belanda.

Di samping menghadapi tantangan dari sistem pendidikan Belanda, pendidikan tradisional Islam, dalam hal ini pesantren, juga berhadapan dengan tantangan yang datang dari kaum reformis atau modernis muslim. Gerakan reformis yang menemukan momentum sejak awal abad ke-20 menuntut diadakan reformulasi sistem pendidikan Islam guna menghadapi tantangan colonialism dan ekspansi Kristen. Dalam konteks ini, reformasi kelembagaan pendidikan modern Islam diwujudkan dalam dua bentuk. Pertama, sekolah-sekolah umum model Belanda tetap diberi muatan pengajaran Islam, seperti sekolah Adabiyah yang didirikan Abdullah Ahmad di Padang pada 1909 dan sekolah-sekolah umum model Belanda yang mengajarkan Al-Qur'an, yang didirikan oleh organisasi semacam Muhammadiyah. Kedua, madrasah-madrasah modern yang pada titik tertentu menganulir substansi dan metodologi pendidikan modern Belanda, seperti sekolah diniyah Zainudin Labay el-Yunusi. ${ }^{28}$

Berkaitan dengan pernyataan di atas, ada benarnya jika kemudian analisis Karel A. Stenbrink dimunculkan. Menurut pengamat keIslaman asal Belanda itu, pesantren meresponi atas kemunculan dan ekspansi sistem pendidikan modern Islam dengan bentuk menolak sambil mengikuti. Komunitas pesantren menolak paham dan asumsi-asumsi keagamaan kaum reformis, tetapi pada saat yang sama mereka juga mengikuti jejak langkah kaum reformis dalam batas-batas tertentu yang sekiranya mampu tetap bertahan. ${ }^{29}$ Oleh karena itu, pesantren melakukan sejumlah akomodasi yang dianggap tidak hanya akan mendukung kontinuitas pesantren, tetapi juga

\footnotetext{
${ }^{28}$ Suwendi, 161

${ }^{29}$ Suwendi, 159.
} 
bermanfaat bagi santri. Dalam wujudnya secara kongkrit, pesantren merespon tantangan itu dengan beberapa bentuk. Pertama, pembaharuan substansi atau isi pendidikan pesantren dengan memasukkan subjek-subjek umum dan ketrampilan. Kedua, pembaharuan metodologi, seperti sistem klasikal dan penjenjangan. Ketiga, pembaharuan kelembagaan, seperti kepemimpinan pesantren, diversivikasi kelembagaan. Dan keempat, pembaruan fungsi, dari fungsi kependidikan untuk juga mencakup fungsi sosial ekonomi.

\section{F. Penutup}

Pesantren tradisional atau pondok pesantren masih dibutuhkan karena mampu memberikan pemenuhan terhadap kebutuhan dalam bidang rohani dan spiritual sebagai kebutuhan abadi manusia. Dalam era modernisasi sekarang ini, di mana dampak negatif dari kemajuan ilmu pengetahuan dan teknologi (IPTEK) lebih besar dirasakan oleh masyarakat terutama dengan munculnya berbagai bentuk dekadensi akhlak/moral manusia, pesantren tradisional masih tetap

relevan untuk tetap dipertahankan. Kemajuan IPTEK telah menyebabkan manusia kehilangan ketentraman dan kebahagiaan mental spiritual akibat persaingan dalam bidang materi, kuatnya dominasi budaya Barat, sifat manusia yang materialistis dan individualistis, serta nafsu manusia yang hanya mementingkan segi-segi kehidupan duniawi dan melupakan akhirat.

Pesantren datang sebagai bentuk penyempurna dari kepingan yang selama ini dicari. Tradisional bukan berarti kuno dan lapuk. Justru ia berorientasi pada penguatan karakter yang sudah lama didesain dalam perencanaan matang dan justru baru didengungkan akhir-akhir ini. Cara tradisional ala pesantren sangatlah dinamis, banyak lini yang bisa lebih dikuatkan dengan cara modern tetapi tetap manusiawi. Itulah mengapa tradisionalisme pesantren justru harus dipertahakan untuk mewujudkan generasi bangsa yang pintar dalam keilmuan sekaligus jujur, cerdas dan kuat secara karakter. 


\section{DAFTAR PUSTAKA}

A. Wahid Zaini, "Orientasi Pondok Pesantren Tradisional Dalam Masyarakat Indonesia", dalam Tarekat, Pesantren, dan Budaya Lokal, ed. M. Nadim Zuhdi et. al. Surabaya : Sunan Ampel Press, 1999.

Ahmad D. Marimba, Pengantar Filsafat Pendidikan Islam, Bandung : Al-Ma'arif, 1974.

Ahmad Qodri A. Azizy, Islam dan Permasalahan Sosial : Mencari Jalan Keluar, Yogyakarta : LKIS, 2000.

Arifin, Imron. Kepemimpinan Kyai : Kasus Pondok Pesantren Tebuireng. Malang : Kalimasahada Press, 1993.

Azumardi Azra, "Pesantren : Kontinuitas dan Perubahan", Pengantar dalam Nucholis Madjid, Bilik-Bilik Pesantren : Sebuah Potret Perjalanan, Jakarta : Paramida, 1997.

Depdikbud RI, Kamus Besar Bahasa Indonesia, Jakarta : Balai Pustaka, 1989.

Dhofier, Zamakhsyari. Tradisi Pesantren : Studi tentang Pandangan Hidup Kyai. Jakarta : LP3ES, 1994.

Dr. Husni rahim, "Arah Baru Pendidikan Islam di Indonesia", Jakarta: PT. Logos Wacana Ilmu 2001.

Ghazali, Bahri. Pendidikan Pesantren Berwawasan Lingkungan. Jakarta : Pedoman Ilmu Jaya, 2001.

Hanun Asrorah, Sejarah Pendidikan Islam, Jakarta: Logos Wacana ilmu, 1999.

Ismail, Faisal. Paradigma Kebudayaan Islam : Studi Kritis dan Refleksi Historis. Yogyakarta : Titian Ilahi Press, 1998.

Malik Fadjar, Visi Pembharuan Pendidikan Islam, Jakarta: LP3N, 1998

Martin Van Bruinessen, Kitab Kuning, Pesantren, dan Tarekat : Tradisi-Tradisi Islam di

Indonesia, Bandung: Mizan, 1999

M. Habib Chirzin, "Agama dan Ilmu dalam Pesantren", dalam Pesantren dan Pembaharuan, ed. M. Dawam Rahardjo Jakarta : LP3ES, 1988.

Nurcholish Madjid, Islam, Kemodernan, dan Keindonesiaan, Bandung : Mizan, 1997.

Sa'id Aqiel Siradj, "Khazanah Pemikiran Islam dan Peradaban Modern", dalam Pesantren Masa Depan : Wacana Pemberdayaan dan Transformasi Pesantren, ed. Marzuki Wahid et. Al, Bandung : Pustaka Hidayah, 1999.

Suwendi , "Rekonstruksi Sistem Pendidikan Pesantren : Beberapa Catatan", dalam Pesantren Masa Depan,

Suwendi, "Sejarah dan Pemikiran Pendidikan Islam", Jakarta: 2004. 
Tim Dosen FIP-IKIP Malang, Pengantar Dasar-Dasar Kependidikan, Surabaya : Usaha Nasional, 1981. 